\title{
Evaluation of a simulation tool in ophthalmology: application in teaching funduscopy
}

\section{Avaliação do uso de um instrumento de simulação em oftalmologia: aplicação no ensino da fundoscopia}

\author{
Joice Elise AndrowikI ${ }^{1}$, Isaac Assis Scravoni ${ }^{1}$, Lucas Holderegger Riccl ${ }^{1}$, Djalma José Fagundes ${ }^{2}$, Caroline Amaral Ferraz ${ }^{3}$
}

\begin{abstract}
Purpose: The aim of this study was to evaluate the Eye Retinopathy Trainer ${ }^{\circledR}$ as a teaching tool for direct ophthalmoscopy examination by comparing it with the traditional method using volunteers.

Methods: Fourth year medical students received training in direct ophthalmoscopy using a simulation tool and human volunteers. Ninety students were randomized into a Simulation Group or a Control Group by the inclusion or absence of the simulation model in classroom practice. Differences between the groups were analyzed using unpaired Student's t-test.

Results: The Simulation Group was superior to the Control Group, with 51.06\% successful in performing fundus examination in both the anatomical model simulation and the human model in comparison with $21.15 \%$ in the Control Group.

Conclusions: The Eye Retinopathy Trainer ${ }^{\circledR}$ appears to be an effective teaching tool for practice and improvement of ophthalmologic examination among fourth year medical students.
\end{abstract}

Keywords: Ophthalmoscopy/education;Ophthalmoscopes/utilization; Simulation; Education, medical; Diagnostic techniques, ophthalmological

\section{RESUMO}

Objetivo: O objetivo desse estudo foi avaliar o Eye Retinopathy Trainer ${ }^{\circledR}$ como ferramenta didática complementar ao treinamento do exame ocular, em comparação ao método tradicional, baseado na aprendizagem com voluntários.

Métodos: Noventa estudantes receberam treinamento em oftalmoscopia direta utilizando um modelo de simulação evoluntários humanos. Os alunos foram divididos em grupo Simulação e em grupo Controle mediante a inclusão ou ausência do simulador no treinamento em aula prática. Diferenças entre os grupos foram analisadas por teste $t$ de Student não pareado.

Resultados: 0 desempenho prático do Grupo Simulador mostrou-se superior ao Grupo Controle, evidenciando que 51,06\% dos alunos do primeiro grupo foram bem sucedidos ao realizar a fundoscopia tanto no modelo anatômico de simulação quanto no modelo humano, comparado a $21,15 \%$ dos alunos grupo Controle.

Conclusões: $O$ simulador Eye Retinopathy Trainer ${ }^{\circledR}$ mostrou ser uma ferramenta didática efetiva para a prática e aprimoramento do exame oftalmológico entre estudantes do quarto ano de medicina.

Descritores: Oftalmoscopia/educação; Oftalmoscópios/utilização; Simulação; Educação médica; Técnicas de diagnóstico oftalmológico

\section{INTRODUCTION}

Based on alarming data from the study entitled "To Err is Human: Building a Safer Health System" ${ }^{\prime \prime}(1,2)$, the medical community has been trying to adopt certain mechanisms to reduce medical errors and to improve patient care. In particular, the use of virtual and physical simulators has been increasingly recommended for training and safety procedures ${ }^{(3,4)}$.

The development of several simulation devices has allowed the reproduction of various clinical situations, creating opportunities for unlimited practice of new skills without involving real patients $s^{(5,6)}$. Therefore, to effectively promote skills transference into clinical practice, medical education needs to advance beyond the traditional methods, complementing current leaning techniques with simulation tools.

In ophthalmology, the use of virtual simulators in the training of specialized physicians has attracted much attention, mainly in surgical education, thereby reducing morbidity during ophthalmologic surgery ${ }^{(7,8)}$. However, simulators can also be adapted for undergraduate education. The medical school of the University of California Davis (UCDAVIS) successfully developed the Eye Examination Simulator ${ }^{\circledR}$, a simulation model that has been effective to teach medical students the cranial nerves examination. In addition, using the Eye Examination Simulator ${ }^{\circledR}$, simulations of extrinsic and intrinsic muscle lesions are possible.
Ophthalmoscopy simulation tools have also been developed. These tools range from unsophisticated equipment ${ }^{(9)}$ to advanced models ${ }^{(10,11)}$, which gather special objects such as mannequins, specific task trainers, simulated patients, and computer-generated scenes, bringing practical learning as close to reality as possible ${ }^{(12)}$. However, the selected tool should be compatible with the level of education of the student because excessive realism and complexity could lead to confusion during the learning and performance of basic skills ${ }^{(13)}$.

In 2007, Pao et al. ${ }^{(14)}$ built a Styrofoam head combining two methods to simulate the retina. Originally called THELMA (The Human Eye Learning Model Assistant), the model uses equipment that projects photographs in one eye (slide method), and an apparatus similar to an eyeball in the other eye (plug method). In the slide method, images of the retina are projected through the coronal temporal region of the head, and placed exactly in the posterior part of the eye of the model. In the plug method, a plug in the shape of a human eye is placed in the model. The plug has a diameter of $17 \mathrm{~mm}$ so the field of vision can reach a wide angle (60 degrees) when visualized with a direct ophthalmoscope. The image of the retina is projected onto the back of the plug, and resized to its natural format.

Adequate visualization of the retina is challenging for most individuals. Therefore, the use of a simulation tool in ophthalmoscopy training could help to familiarize medical students and general phy-
Submitted for publication: August 4, 2014

Accepted for publication: November 11, 2014

School of Medicine, Anhembi Morumbi University - Laureate International Universities, São Paulo, SP, Brazil.

Department of Surgery, Federal University of São Paulo, São Paulo, SP, Brazil.

Department of Ophthalmology, School of Medicine, Anhembi Morumbi University - Laureate International Universities, São Paulo, SP, Brazil.
Funding: No specific financial support was available for this study.

Disclosure of potential conflicts of interest: None of the authors have any potential conflicts of interest to disclose.

Corresponding author: Joice Elise Depoli Androwiki. Rua Helena do Sacramento, 184 - São Paulo, SP - 02433-020 - Brazil -E-mail: joiceandrowiki@hotmail.com

Approved by the following Research Ethics Committee: Anhembi Morumbi University - Laureate International Universities (number 04532512.0.0000.5492). 
sicians with changes related to pathological conditions ${ }^{(8)}$. This study evaluates the Eye Retinopathy Trainer ${ }^{\circledR}$ as a teaching tool for direct ophthalmoscopy examination, and compares the use of the tool with the traditional approach using human patients.

\section{METHODS}

This prospective, rater-blinded, comparative study was approved by the Ethical and Research Committee of Anhembi Morumbi University. All participants, volunteers, and students provided informed consent. The study was conducted from August to December 2012.

\section{Participants}

Ninety medical student volunteers from the central campus of Anhembi Morumbi University, São Paulo, took part in the study. All participants were fourth-year medical students with previous clinical knowledge in the area of ophthalmology.

\section{Procedure}

The students were paired and randomized by simple raffle into two groups. The students in the Control Group (CG) attended an ophthalmology lesson presented in Microsoft Office PowerPoint ${ }^{\circledR}$ with slides on how to perform an ophthalmoscopy examination and underwent practical direct ophthalmoscopy training with human volunteers. The students in the Simulation Group (SG), attended the same theoretical lesson, and were also enrolled in a practical experimental class using the simulation tool Eye Retinopathy Trainer ${ }^{\circledR}$ (white model; Adam, Rouilly, Sittingbourne, Kent, UK; Figure 1). This simulator consists of a human-based model equipped with an ocular display that allows the visualization of several retinal images: normal, diabetic retinopathy, hypertensive retinopathy, acute and chronic papilledema, optic atrophy due to glaucoma, toxoplasmosis, central vein occlusion, post-photocoagulation central vein occlusion, and age-related macular degeneration. The following images were used in the present study: normal retina, hypertensive retinopathy, diabetic retinopathy, and acute papilledema.

The total training time was the same for both groups and consisted of four periods of four hours. At the end of training, both groups underwent a practical exam. Each student was evaluated individually by performing the following:

1) Ophthalmoscopy in the simulation model (Figure 2).

2) Ophthalmoscopy in a previously selected volunteer from the Simulation Center of the University.

During the exam, each student had to describe the optic nerve characteristics (color aspects, cup-to-disc ratio), blood vessels (absence of arteriovenous nicking or vascular tortuosity), optic disc edges (limits and regularity), and macular aspects (brown color and natural brightness), observed during ophthalmoscopy in the human volunteer and/or in the simulation model. The score ranged from 0 to 10 , according to table 1 .

For both models (volunteer or simulator), the description of a normal retina was expected, once it was not used any pathological examples in the exam.

\section{Statistical analysis}

Results are presented as means and standard deviations of absolute values or percentages of numerical samples. Differences between groups were analyzed using an unpaired Student's $t$-test. Values of $p<0.05$ were considered statistically significant. ANOVA was also performed with similar results to the unpaired Student's $t$-test.
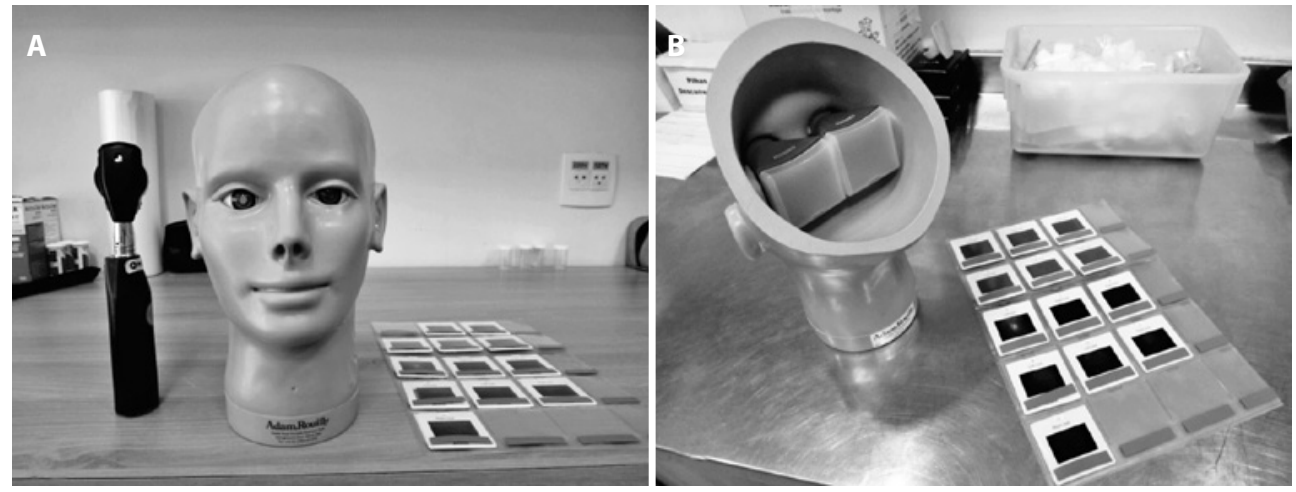

Figure 1. The Eye Retinopathy Trainer ${ }^{\oplus}$, an anatomically correct simulator. Images are positioned in the back of the mannequin head.
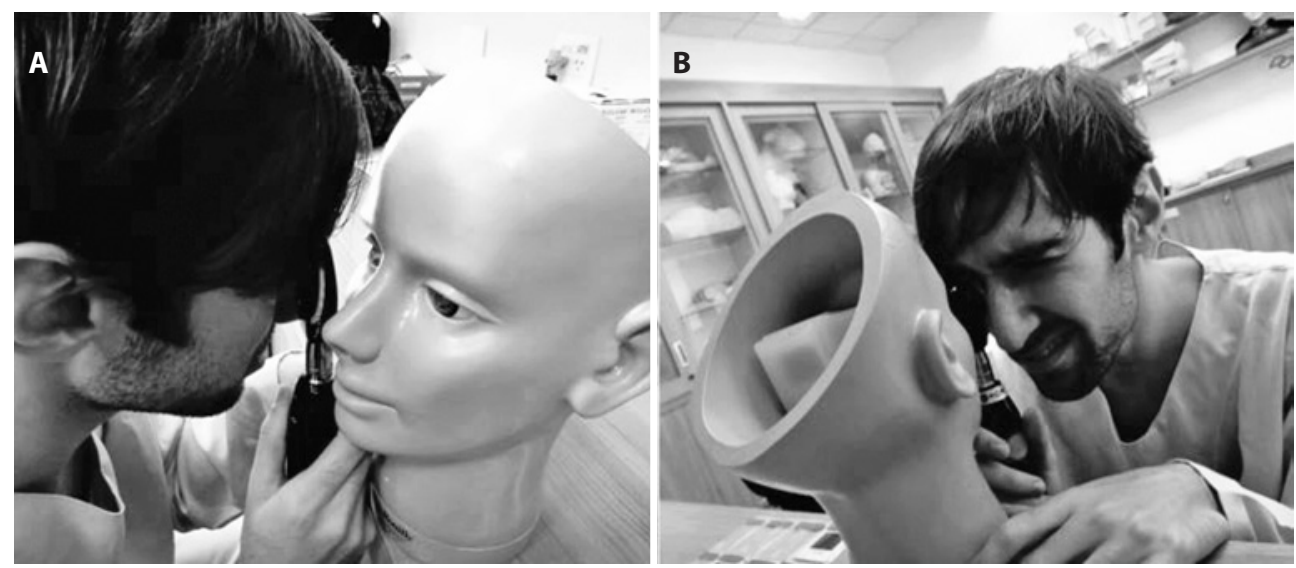

Figure 2. Example of a student preforming an ophthalmoscopy examination in the simulation model during the practical exam. 
We sought to verify significant differences in practical performance, comparing two distinct groups of students in a random sample to confirm or discard a specific theory. In this study, the difference between groups was participation in practical classes with the Eye Retinopathy Trainer ${ }^{\circledR}$, and the theory in question refers to the efficacy of this simulator for ophthalmology teaching programs.

\section{RESULTS}

The results were evaluated according to the following parameters: (1) Average score and its distribution, in arbitrary units; (2) Performance during the practical exam, comparing both groups; (3) Statistical difference in performance between the two groups in the practical exam.

\section{Average score (theoretical and practical exams)}

There was no statistical difference between the groups for the average score in the theoretical and practical exams (Figures 3 and 4).

\section{Performance during the practical exam}

In CG, $11.53 \%$ of the students managed to visualize the fundus adequately in the simulation model (D+), 15.38\% in the human model $(\mathrm{H}+)$, and $21.15 \%$ in both models $(\mathrm{D}+/ \mathrm{H}+)$. In SG, $12.76 \%$ of the students managed to visualize the fundus adequately in the simulation model $(\mathrm{D}+), 12.76 \%$ in the human model $(\mathrm{H}+)$, and $51.06 \%$ in both models $(\mathrm{D}+/ \mathrm{H}+)$ (Figure 5$)$.

The performance in the practical exam was poorer in CG than in SG, with $57.7 \%$ of students in CG unable to visualize the fundus correctly in the dummy or in the human model (D-/H-), compared with $23.4 \%$ of SG students.

\section{Statistical difference in the practical exam}

The unpaired Student's t-test showed a significantly better performance $(p<0.0001)$ in the practical exam by students in SG. More

Table 1. Score composition for ophthalmoscopy in human volunteers or the simulation model

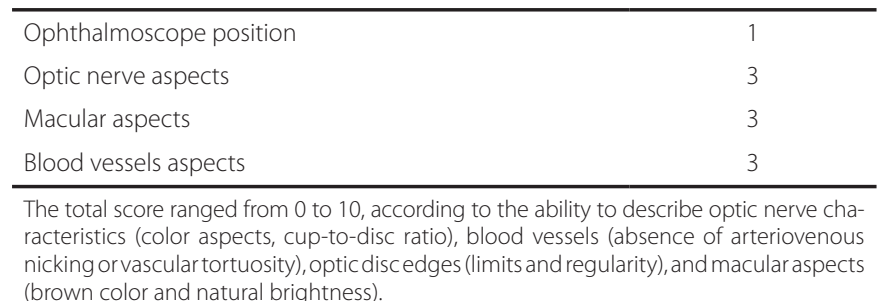
(brown color and natural brightness).

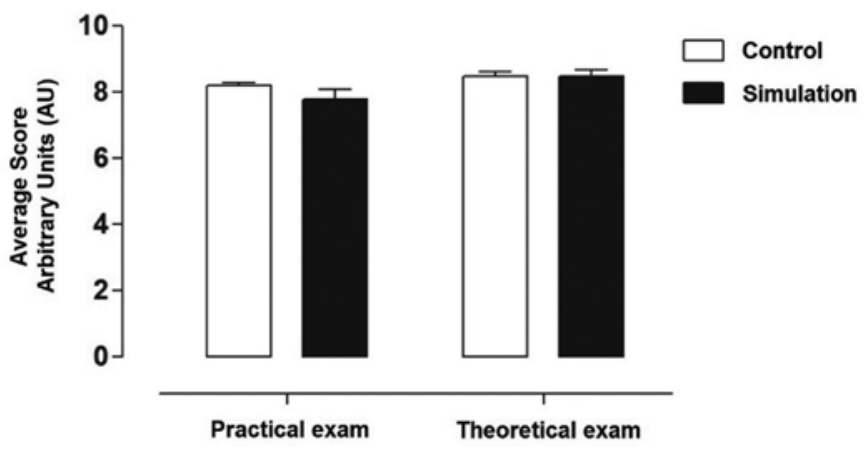

Figure 3. Average scores in the theoretical and practical exams for the simulation and control groups. There is no statistically significant difference between the groups.
SG students were able to visualize the fundus adequately in the dummy model $(\mathrm{D}+)$, the human model $(\mathrm{H}+)$, and in both models $(\mathrm{D}+\mathrm{s}$ $\mathrm{H}+$ ). Therefore, compared with CG, significantly fewer students in SG could not visualize the fundus adequately in either model (D-/ $\mathrm{H}-$ ). Finally, the avalue of $\mathrm{p}<0.05$ versus $\mathrm{D}+/ \mathrm{H}+$ indicates that the null hypothesis is false. In other words, training with an anatomical simulator could provide benefits in ophthalmoscopy learning.

\section{DISCUSSION}

In this study, the Eye Retinopathy Trainer ${ }^{\circledR}$ proved to be capable of providing didactic learning of funduscopy, with enhanced quality of acquired skills in students in SG. However, some of the differences observed between CG and SG could be the result of other variables that were not considered in this study, for example, emotional state, interest, and the individual commitment of each student. It is also important to note that SG might have achieved a better performance because of continuous periods of training with the dummy, because it is not necessary to take breaks during the examination to minimize discomfort for the human volunteer.

Virtual simulation devices can create numerous scenarios that allow repeated practice of procedures and examinations, without patient contact. The didactic potential of these models in medical learning is unquestionable ${ }^{(14,15)}$. On the other hand, simulation training compromises the development of the physician-patient relationship, and high technological costs and the requirement for specially trained staff may be considered limitations.

This study has several limitations. The number of participants was small, and the assessment of training was only performed in the short term. However, the preliminary results might provide background data to help the development of new projects for other simulation tools.

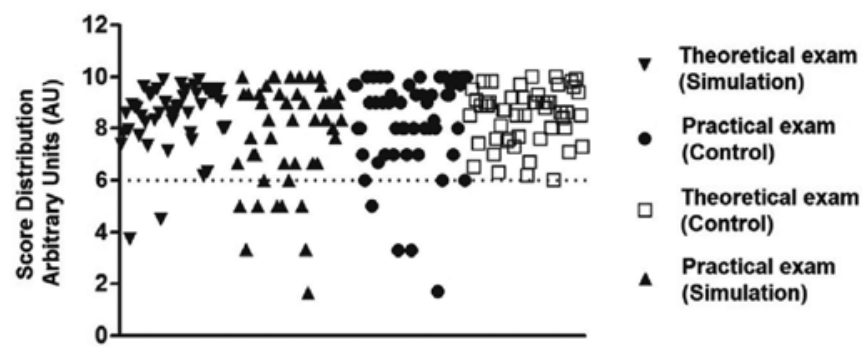

Figure 4. Distribution of test scores in the theoretical and practical exams for each student in each group. There is no statistically significant difference between the groups.

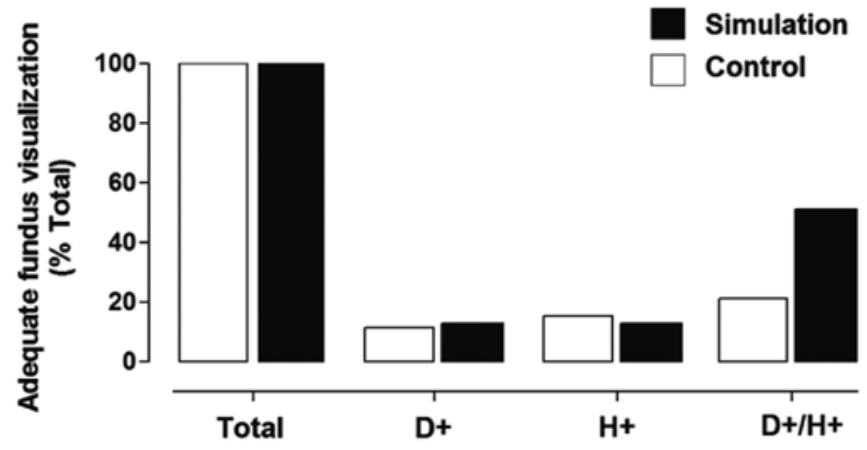

Figure 5. Comparison between the percentage of students able to visualize the fundus adequately, in each group and in each model. 


\section{REFERENCES}

1. Satava RM, Jones SB. Current and future applications of virtual reality for medicine Proc IEEE. 1998;86(3):484-9.

2. Kohn LT, Corrigan JM, Donaldson MS. To err is human: building a safer health system. Washington, DC: National Academy Press; 1999.

3. Champion H, Gallagher A. Simulation in surgery: a good idea whose time has come. Br J Surg. 2003;90(7):767-8

4. Dawson SL. A critical approach to medical simulation. Bull Am Coll Surg. 2002;87(1): $12-8$

5. Rall M, Dierckmann P. Crisis resource management to improve patient safety. In: Eu roanesthesia, 2005. Vienna, Austria 28-31 May 2005.

6. Weller JM, Nestel D, Marshall SD, Brooks PM, Conn JJ.Simulation in clinical teaching and learning. Med J Aust. 2012;196(9):594.

7. O'Toole RV, Playter RR, Krummel TM, Blak WC, Cornelius NH, Roberts WR, et al. Measuring and developing suturing technique with a virtual reality surgical simulator. $J$ Am Coll Surg. 1999;189(1):114-27.
8. Carvalho JA. Oftalmologia e realidade virtual. Rev Bras Oftalmol. 2012;71(1):40-7.

9. Chung KD, Watzke RC. A simple device for teaching direct ophthalmoscopy to primary care practioners. Am J Ophthalmol. 2004;138(3):501-2.

10. VRmagic Co. Direct ophthalmoscope simulator [Internet]. [cited 2014 Sep 25 ] Available from: http://www.vrmagic.com/fileadmin/downloads/simulator_brochures/ Eyesi_Direct_Brochure_131029_EN_WEB_DP.pdf

11. McCarthy DM, Leonard HR, Vozenilek JA. A new tool for testing and training ophthalmoscopic skills. J Grad Med Educ. 2012;4(1):92-6.

12. Filho JB. Leite DA. Castro AR. Andrade LS. Avaliação dos conhecimentos oftalmológicos básicos em estudantes de Medicina da Universidade Federal do Piauí. Rev Bras Oftalmol. 2011;70(1):27-31.

13. Maran N, Glavin R. Low to high-fidelity simulation - a continuum of medical education? Med Educ. 2003;37 Suppl 1:22-8

14. Pao KY, Uhler TA, Jaeger EA. Creating THELMA - The Human Eye Learning Model Assistant. J Acad Ophthalmol. 2008;1(1):25-9.

15. Weller JM, Nestel D, Marshall SD, Brooks PM, Conn JJ. Simulation in clinical teaching and learning. Med J Aust. 2012;196(9):594.

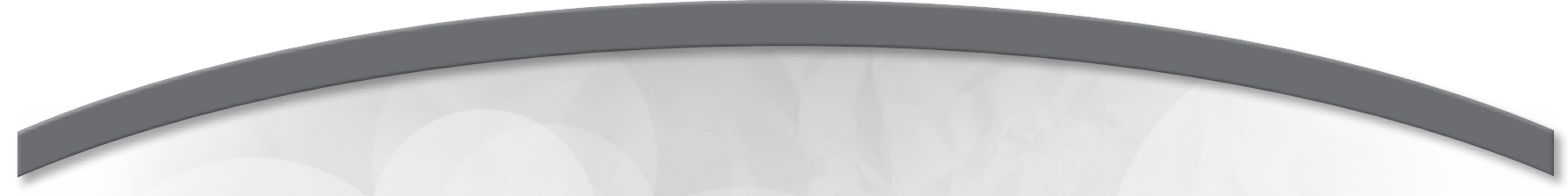

\title{
XXI Congresso Norte Nordeste de Oftalmologia
}

\author{
26 a 28 de março de 2015 \\ Serhs Natal Grand Hotel \\ Natal - RN
}

\section{Informações:}

Site: www.snno.com.br

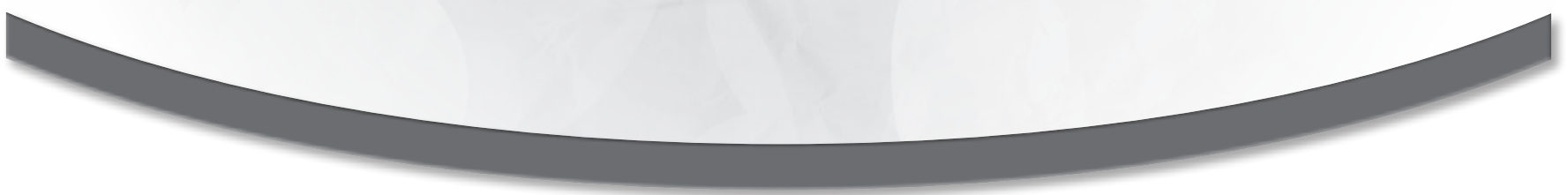

